\title{
Bench Tests for Exhaust Gas Temperature Distribution in an Aircraft Piston Engine with and without a Turbocharger
}

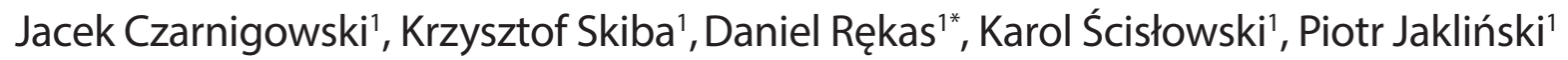 \\ 1 Faculty of Mechanical Engineering, Department of Thermodynamics, Fluid Mechanics and Aviation \\ Propulsion Systems; Lublin University of Technology, ul. Nadbystrzycka 36, 20-618 Lublin, Poland \\ * Corresponding author's e-mail: d.rekas@pollub.pl
}

\begin{abstract}
In ultralight aviation, a very important engine parameter is the power-to-weight ratio. On the one hand, there is a tendency to minimize the size and weight of engines, and on the other hand, there is a demand to achieve the highest possible power by using supercharging systems. Increasing power brings many benefits, but it also increases temperature in the exhaust system, posing a threat to delicate parts of the ultralight aircraft fuselage. Therefore, it is necessary to control temperature values in the engine exhaust system. This article presents the temperature distribution in the exhaust system of an aircraft engine by the example of a four-cylinder Rotax 912 engine with an electronic fuel injection system. The research was conducted in two stages: measurements were made first for the engine without a turbocharger with an original exhaust system and later for its modified version with an added turbocharger system. The paper presents a comparative analysis of exhaust gas temperatures measured at three points: 30,180 and $1000 \mathrm{~mm}$ from the cylinder head. The tests were conducted for the same preset engine operating conditions at constant speed and manifold air pressure. It has been shown that the exhaust temperature in the exhaust manifold decreases with the distance from the cylinder head. The highest gradient, over three times higher than the gas temperature from $589.9^{\circ} \mathrm{C}$ to $192.3{ }^{\circ} \mathrm{C}$, occurred in the manifold with a turbocharger for $2603 \mathrm{RPM}$ and $31 \mathrm{kPa}$ of manifold air pressure. The introduction of turbocharging causes an increase in exhaust gas temperatures before the turbocharger by an average of $12 \%$, with this increase being greater for operating points of higher inlet manifold pressure. Turbocharging also causes a significant decrease in exhaust gas temperatures behind the turbocharger and the silencer because the temperature drops there by an average of $25 \%$.
\end{abstract}

Keywords: piston engine, exhaust system, temperature distribution, turbocharging, Rotax 912.

\section{INTRODUCTION}

The authors of the reports $[1,2]$ claim that aviation is currently one of the fastest growing industries in the world. New technologies and materials enable the construction of very light vessels, while maintaining their dimensions [3]. The decisive argument is obviously the economic aspect. Less weight translates directly into lower fuel consumption so lower operating costs. Not only the way aircraft airframe is constructed is being dynamically modified, but also materials used for engines are changing. Extensive scientific and laboratory research [4] to develop a new generation of aerospace materials with excellent mechanical parameters, thermal resistance and corrosion resistance enable to obtain more power with a simultaneous reduction of mass and a longer resale time of the propulsion unit Consequently, more cargo can be transported, long-range cargo transportation is possible or emissions of carbon dioxide and other substances harmful to the atmosphere can be reduced [5]. New technologies and materials are also used to construct ultra-light aircraft. The results of the reports [6] show that there is a growing demand for ultra-light and light passenger and unmanned aerial vehicles (UAVs) in the global aviation market. Today, ultra-light and light aircraft market surpassed USD 4.8 billion and is anticipated to grow between 2020 and 
2026 by around 9\% CAGR (Compound Annual Growth Rate). This trend is very clear in developed economies that are increasingly interested in fast urban and interurban transport. Ultralight aircraft with new electronic flight aid systems and improved passenger safety through the integration of advanced technologies drive the market [7]. Automatic piloting and landing systems, GPS navigation systems and approach systems for the selected ice rink with the possibility of vertical take-off and landing area are being developed. There are also new electric $[8,9]$ and hybrid drive systems $[10,11]$ with electronic systems that increase engine efficiency. They also increase consumption of electric energy. Electric power can be generated by taking some of the power away from the engine shaft, but this results in a decrease in power output. A common solution to increase the useful power of the engine is to use supercharging or turbocharging systems for the internal combustion engine. The turbocharger reduces to a certain extent the flow of hot gases from the engine, increasing the proportion of residual exhaust gas in the cylinder $[12,13]$. The increase in engine power and the throttled flow of exhaust gases increases the energy loss and the temperature rise in the cylinder and exhaust system $[14 \div 17]$.

Currently, most ultra-light aircraft, helicopters and autogyros run on ROTAX 912 ULS piston engines. These motors have a number of advantages such as: satisfactory power-to-weight ratio, easy operation and installation, low production and operating costs, good reliability, sufficient resilience. To increase the power-to-weight ratio, designers use supercharging systems, mostly based on turbocharging systems [18, 19]. Such a solution increases both power of the engine and temperature of the exhaust system, which is dangerous for airframe construction elements, mostly made of composite materials.

There are many advantages of power power boosting by means of supercharging, but it should be noted that as power is increased, the temperature of the gases in the exhaust system also increases $[20 \div 23]$. It is therefore necessary to control temperature values, especially for ultralight aircraft $[24 \div 26]$. Their construction is often based on composite and polymer materials, which are not resistant to high temperatures [27]. The small space of the engine compartment causes heated parts of the exhaust system to come dangerously close to the hull plating $[28,29]$. The introduction of a turbocharging system additionally reduces the amount of space in the engine compartment, while at the same time increasing the distance exhaust gases have to travel before they are discharged outside the engine compartment. The application of turbocharging requires the rebuilding of the engine exhaust system, fuel supply and power control system $[30 \div 32]$. The exhaust flow in a supercharged engine has different characteristics than in a naturally aspirated one and is accompanied by different physical effects $[33 \div 35]$. The heat energy accumulated in exhaust gases is transferred to the environment through walls of the exhaust system as well as external surfaces of compressor, and therefore it is necessary to determine temperatures of individual components $[36 \div 38]$. The temperature of exhaust system components should reach values that are safe for composite materials and plastics, as their damage could have fatal consequences [39]. By knowing thermal emission values of the system, it is possible to redesign the exhaust system so that when built into an aircraft it does not come into close contact with thermally sensitive components [40 $\div 42]$. Knowledge of exhaust gas temperature can also provide information on the operating condition of the engine [43]. A number of studies have been carried out to compare different measuring methods for analyzing temperature of exhaust gases and exhaust system components [44, 45]. The results are highly scattered. The authors state that supercharging raises the temperature in the range from 1 to $10 \%$ depending on the design and operating conditions of the engine. However, most of those works present results only for supercharged engine and refer to temperature of non-supercharged engine from data averaged from literature. There is lack of comparative tests for one engine design. In addition, measurements are made at a single point on the exhaust system, just behind the cylinder head. This temperature is important for the head design. There is lack of information in the lietarture about the temperature distribution along the length of the exhaust system, which is important for the construction of the engine hood system. It is therefore necessary to provide a complement to this knowledge.

This article presents the results of the research on the influence of the turbocharger assembly on the exhaust gas temperature distribution in the exhaust system. 


\section{RESEARCH OBJECT}

The ULS Rotax 912 engine (Fig. 1) is a version of the 912 series engine with a new electronically controlled fuel injection system. It is used in ultra-light, light sport aviation and unmanned aerial vehicles. Rotax engines represent the largest part of the light aviation market in Europe.

The research engine was modified in two stages. In the first stage, the power system was changed by replacing two carburetors with an electronically controlled multi-point indirect fuel injection system - MPFI. A dedicated engine controller was used to determine the injection dose based mainly on the indication of the pressure in the intake manifold (MAP), with the possibility of correcting its operation based on a signal from the oxygen content sensor in the exhaust gases. The engine intake system also underwent changes. A new inlet manifold, a throttle valve and inlet pipes were designed. The next stage included the extension of the intake system and installation of the Garrett GT2860RS (Fig. 2) turbocharger in the exhaust system. The turbocharger on the hot side of the turbine was equipped with a wastegate valve built into the turbocharger's body located between the pipe at the inlet to the turbine (1) and the exhaust manifold (3). It was responsible for regulating the amount of exhaust gas that reaches turbine blades (2) and adjusting compressor speed and maintaining the specified maximum recharge pressure without exceeding it. The regulator was a pneumatic pressure system connected to the intake system behind the compressor. As recharge pressure increased, the valve flap opening angle $(\alpha)$ increased. When the maximum preset recharge pressure was reached, the valve opened, causing the excess exhaust gas to be directed through a bypass channel straight to the exhaust system, without the turbocharger. Thanks to this process, the turbocharger did not exceed the maximum permissible charge pressure and the engine the maximum permissible compression. However, it affected the temperature distribution in the exhaust system.

Figure 3 shows the performance characteristics of the Garrett GT2860RS as a function of exhaust gas mass flow rate and boost pressure. The characteristics indicates the point of operation of the engine at take-off power.

Table 1. ROTAX 912 engine parameters

\begin{tabular}{|l|c|}
\hline Engine configuration & Flat engine (boxer) \\
\hline Cylinder number & 4 \\
\hline Displacement & $1352 \mathrm{cc}$ \\
\hline Maximal power & $\begin{array}{c}73.5 \mathrm{~kW}(100 \mathrm{HP}) \text { at } 5800 \\
\text { RPM }- \text { limited to 5 minutes }\end{array}$ \\
\hline Continuous power & $69 \mathrm{~kW}(93 \mathrm{HP})$ at 5500 RPM \\
\hline Maximal torque & $128 \mathrm{Nm}$ at 5100 RPM \\
\hline Weight & $56.6 \mathrm{~kg}$ \\
\hline Gearbox ratio & 2.43 \\
\hline Bore & $84 \mathrm{~mm}$ \\
\hline Stroke & $61 \mathrm{~mm}$ \\
\hline Compression ratio & $10.8: 1$ \\
\hline Fuel & RON95 \\
\hline
\end{tabular}

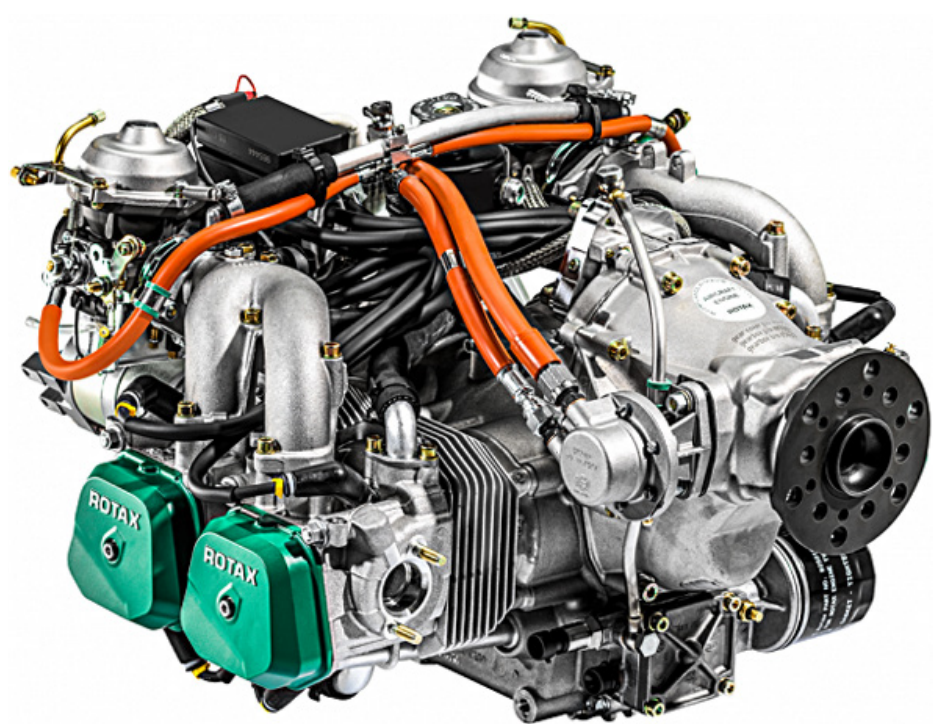

Fig. 1. ROTAX 912 ULS Engine 


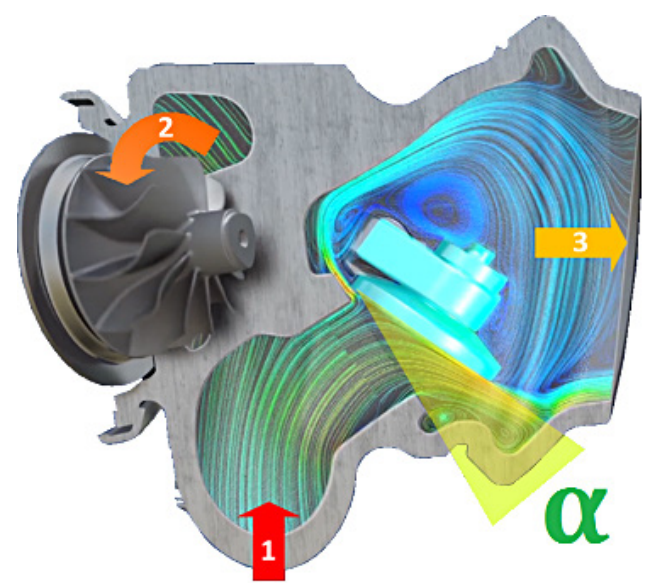

Fig. 2. Exhaust gas flow through the wastegate valve of the Garrett GT2860RS turbocharger

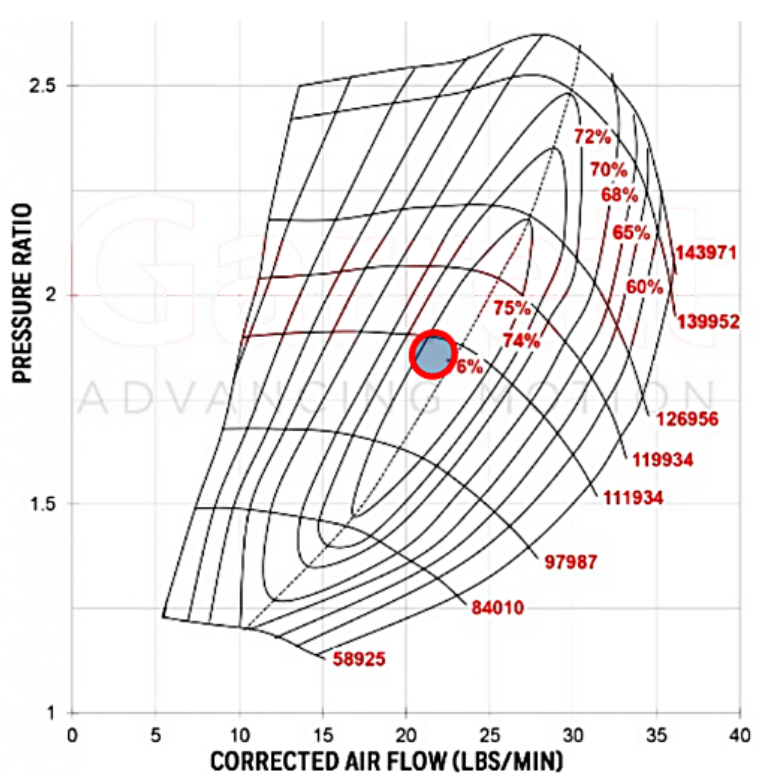

Fig. 3. Compressor map of the Garrett GT2860RS. The blue point marks the maximum efficiency point of the test engine

\section{TEST STAND}

The exhaust gas temperature distribution was tested in the Rotax 912 engine exhaust system without and with the turbocharger. The measurement path was laid along the exhaust system from the first cylinder. Measuring points were determined at 30,180 and 1000 $\mathrm{mm}$ from the cylinder head. Figure 4 shows the location of the measuring points in the original engine exhaust system without the turbocharger. Sensors no. 1 and 2 were placed in the section of the individual exhaust pipes from the cylinders and sensor no. 3 in the exhaust pipe behind the silencer.
The diagram in Figure 5 depicts the arrangement of the sensors installed at the identical distances between the measuring points of the sensors and the head in the engine with the turbocharger as in the previous configuration. Sensors no. 1 and 2 were placed in the section before the turbocharger and sensor no. 3 in the exhaust pipe behind the silencer.

The measurements were performed using type $\mathrm{K}$ thermocouples (NiCr-NiAl) to measure probe performance with trade mark TP-204K-1b-150-1 sensors manufactured by Czaki Thermo - Product. Dedicated KPM8x1-3-St mounting adapters were used to mount the sensors and enabled the sensor parts to be mounted centrally in the exhaust system. The mounted sensor is in Figure 6.

The temperature was recorded with the National Instruments measuring equipment. The signal from the sensors was transferred to the NI 9213 measurement card located in the

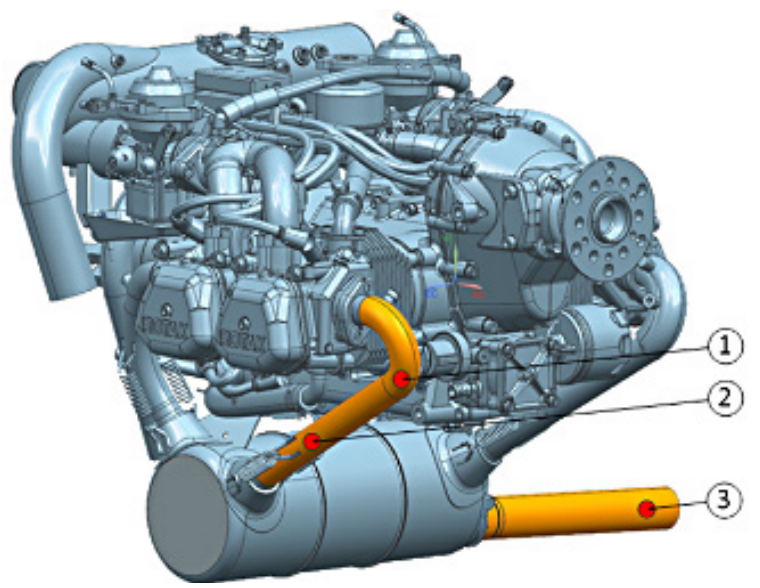

Fig. 4. Arrangement of the sensors in the engine exhaust system without the turbocharger

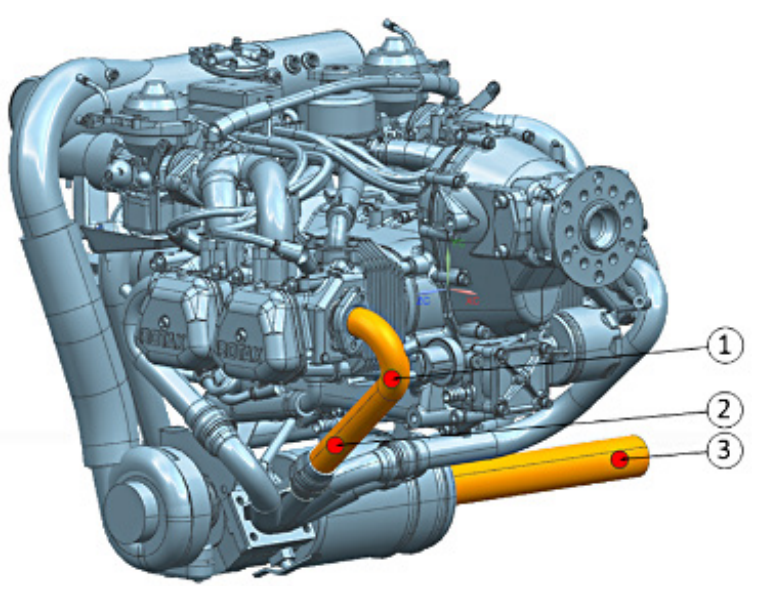

Fig. 5. Arrangement of the sensors in the engine exhaust system with the turbocharger 


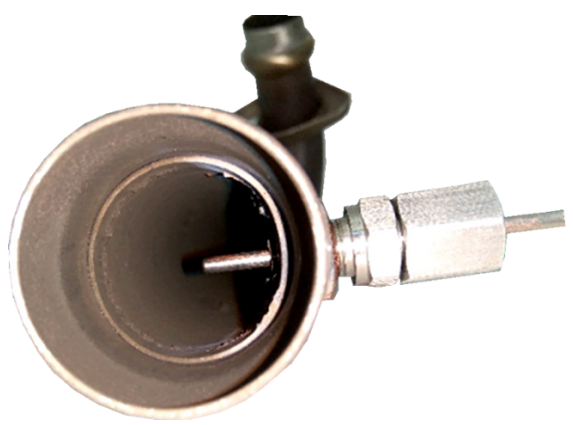

Fig. 6. Mounted TP-204K-1b150-1temperature sensor
CompactDAQ Chassis cDAQ-9174 module slot to perform many simultaneous and synchronous measurements, to process signals from the measurement cards and to transmit them digitally to a computer. LabVIEW 2017 National Instruments were used for digital visualization and recording the results. The graphical interface and the measurement script are shown in Figure 7.

The bench tests were carried out in the laboratories of the CIiZT of the Lublin University of Technology using a water-cooled Elektromex
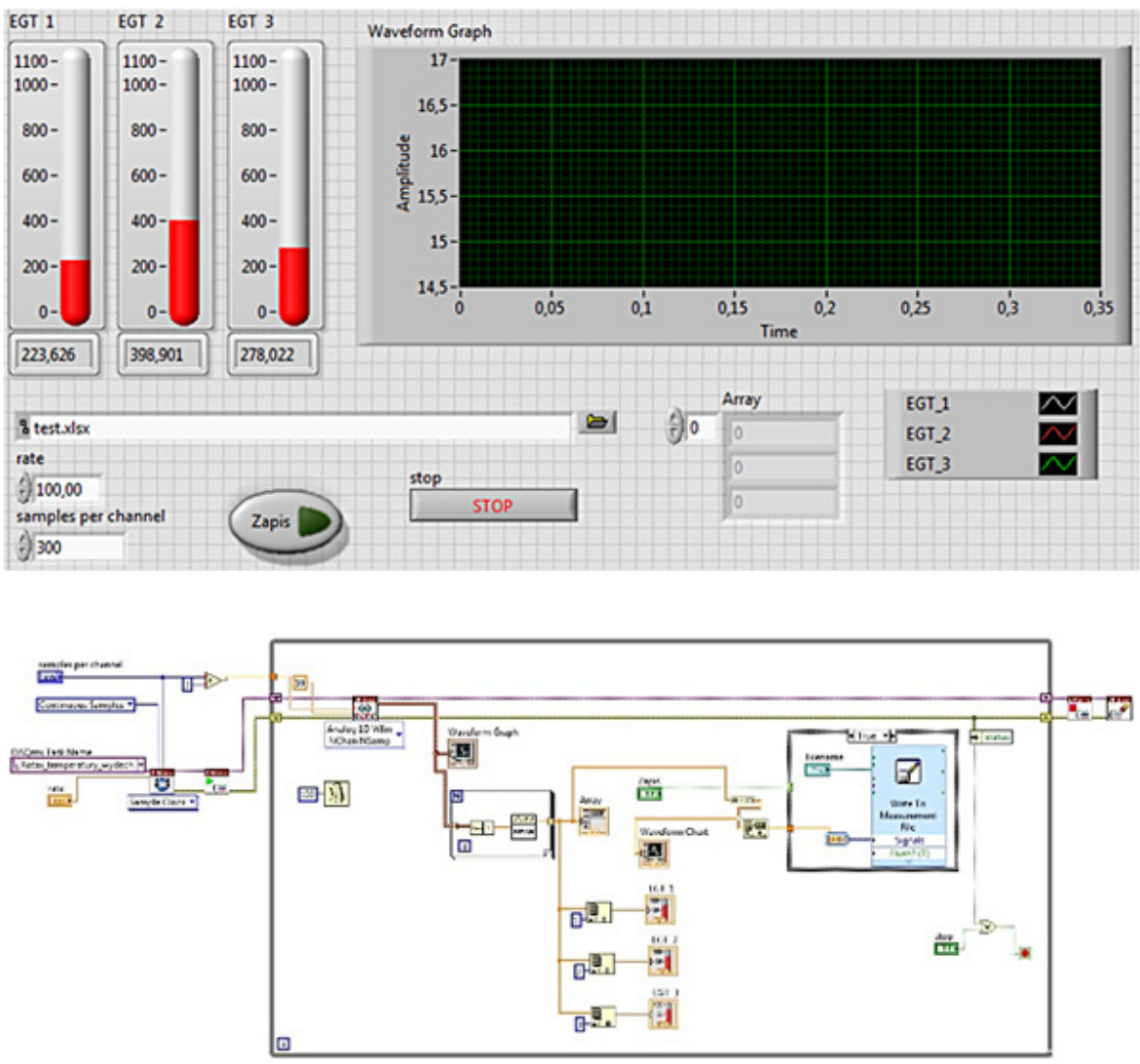

Fig. 7. Research software

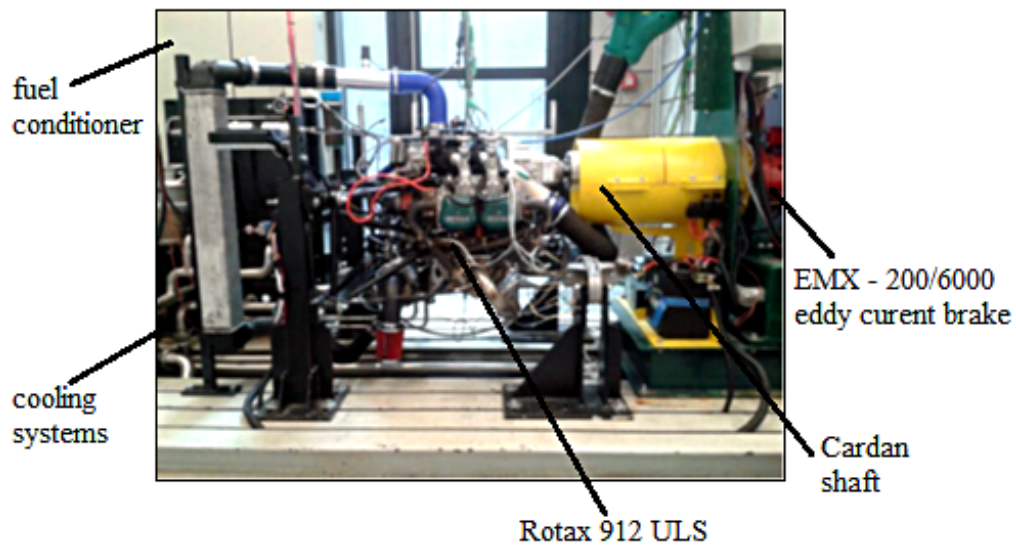

Fig. 8. Test stand 
Centrum - EMX - 200/6000 eddy current brake which enables the testing of motors up to $200 \mathrm{~kW}$ at a speed of 6000 RPM. The brake is compatible with the ATMX 2000 electronic control system manufactured by Automex and a fuel consumption measuring system integrated in the ATMX 2400 fuel conditioner with a fuel temperature and pressure control system.

\section{SCOPE OF RESEARCH}

The purpose of the tests was to measure the gas temperatures in the boxer engine exhaust system without and with the turbocharger. The tests were performed in two stages. The first part of the tests was performed on the engine with an injection system and without the turbocharger. The tests were carried out at 23 steady state engine operating points in the intake manifold with $28 \div 98 \mathrm{kPa}$ of air pressure in the manifold and a speed range of $2000 \div 4600$ RPM (Fig. 9). The second part of the tests was carried out on the engine with an injection system and the turbocharger. The measurements were repeated for the same as in the first part 23 engine operating points. The engine speed was controlled by the brake - by changing the load on the engine to achieve the desired rotational speed. The manifold air pressure control was achieved by using the throttle opening degree.

At each operating point, the temperature was measured at the three distances:

1) in the individual exhaust pipe at $30 \mathrm{~mm}$ from cylinder no 1 ;

2) in the individual exhaust pipe at $180 \mathrm{~mm}$ from cylinder no 1 ;

3) in the exhaust pipe behind the silencer at 1000 $\mathrm{mm}$ from cylinder no 1 .

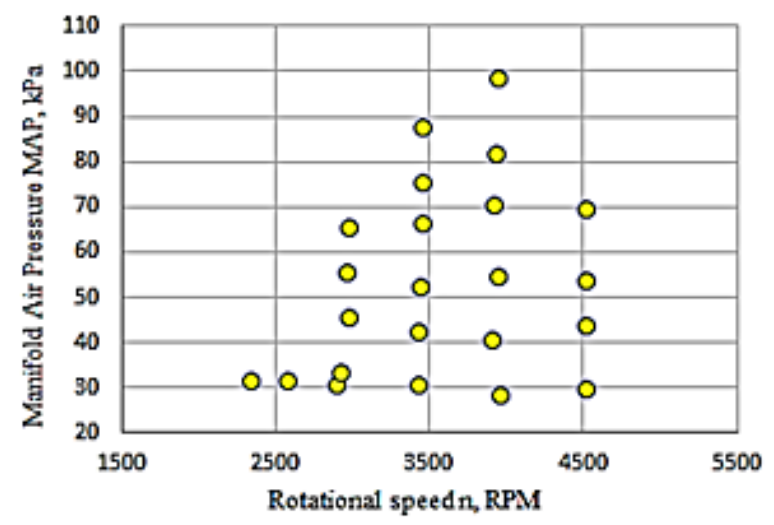

Fig. 9. Engine operating points used in the research
The tests were carried out with the engine warmed up to a temperature of $50^{\circ} \mathrm{C}$. The reading of the values followed a stabilisation of conditions that lasted approximately 10 seconds. The mean value at each measurement point was determined from approximately 100 samples. The standard deviation of the temperature at the analysed points was $1 \div 2{ }^{\circ} \mathrm{C}$.

\section{RESULTS}

The obtained test results on the temperature distribution are presented as 3D diagrams on the following figures. The exhaust gas temperature is presented as a function of engine speed and air pressure in the manifold. A surface grid described by a second degree polynomial was generated from the obtained points. The analysis of the obtained results began with a comparison of the characteristics of gas temperatures in the exhaust systems at measurement point 1 (30 $\mathrm{mm}$ from the head).

The values of gas temperatures in the first measurement point in the engine without the turbocharger are shown in Figure 10. As the speed and pressure in the engine intake system increase, the temperature of exhaust gases also increases. The highest temperature of $713.3{ }^{\circ} \mathrm{C}$ is recorded for $4530 \mathrm{RPM}$ and $69 \mathrm{kPa}$ of manifold air pressure, whereas the lowest one is $551.0{ }^{\circ} \mathrm{C}$ at $2360 \mathrm{RPM}$ and $28 \mathrm{kPa}$.

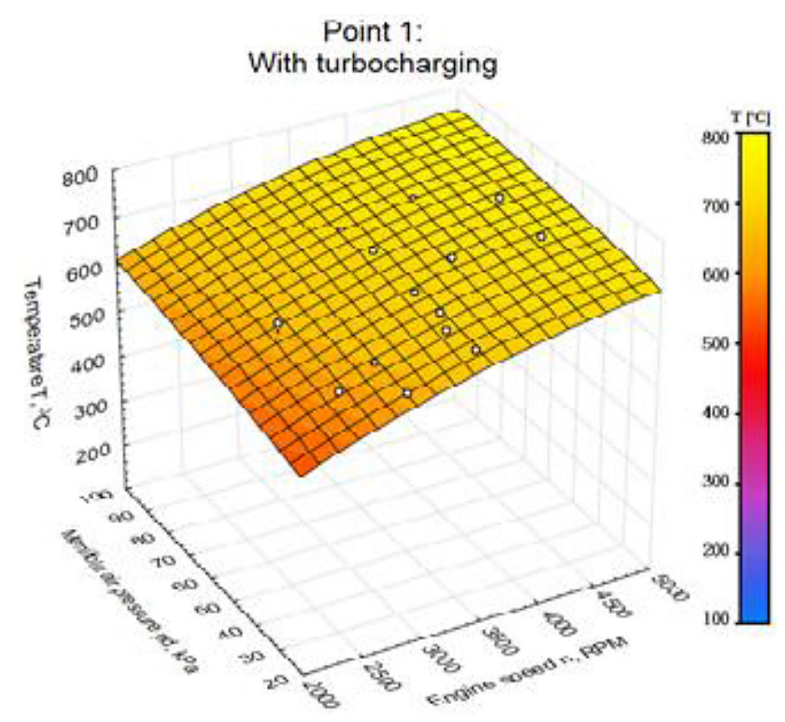

Fig. 10. Exhaust gas temperature at measurement point 1 as a function of rotational speed and manifold air pressure in the engine without turbocharging 
The temperature characteristics at measuring point no. 1 for the engine with the turbocharger is shown in Figure 11. In this configuration also as the speed and pressure in the engine intake system increase, the temperature of exhaust gases increases. The maximum temperature of $736.8{ }^{\circ} \mathrm{C}$ is recorded for the engine operating at the highest speed of $4530 \mathrm{RPM}$ and $69 \mathrm{kPa}$ of manifold air pressure, whereas its minimum value of $558.2{ }^{\circ} \mathrm{C}$ is recorded for a rotational speed of $2360 \mathrm{RPM}$ and a pressure of $28 \mathrm{kPa}$. Both for supercharged and undercharged engine the values of temprature in this point are in accordance with literature data. $[44,45]$. They are also consistent with the engine manufacturer's published data for acceptable engine exhaust gas temperatures at this point.

The installation of the turbocharger and the modification of the exhaust system resulted in the change of exhaust gas temperature values for all 23 test points of engine operation. The Figure 12 shows a complete characteristics of temperature changes as a function of manifold air pressure and speed. The increase of exhaust gas temperatures in the turbocharged engine is proportional to the increase of manifold air pressure and inversely proportional to speed in the area of low manifold air pressure. The temperature increase of $74.5{ }^{\circ} \mathrm{C}$ is highest at $2360 \mathrm{RPM}$ and $28 \mathrm{kPa}$, while at $4590 \mathrm{RPM}$ and $29 \mathrm{kPa}$ the temperature maintenance of the exhaust gas in the turbocharger system is much

Point 1:

With turbocharging

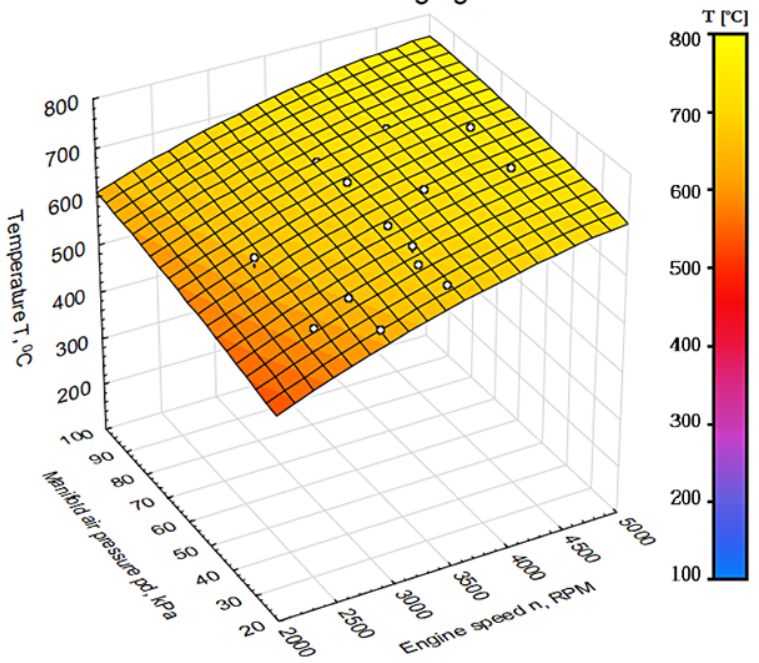

Fig. 11. Exhaust gas temperature at measurement point 1 as a function of rotational speed and manifold air pressure in the engine with turbocharging better than the original exhaust system. The average exhaust gas temperature for an engine without the turbocharger is $646.3{ }^{\circ} \mathrm{C}$, whereas the one for the turbocharged engine is $19.1 \mathrm{de}-$ grees higher. At a distance of $30 \mathrm{~mm}$ from the cylinder, a slight $3 \div 6 \%$ temperature rise is noticeable. This increase results from the higher engine load (intake manifold pressure). The change is practically insignificant at low loads when the turbine does not work. Thus, supercharging at higher loads causes an increase in the temperature of the expansion end, which results in an increase in the temperature of the entire process (and thus also in an increase in generated power).

The temperature characteristics obtained from measurement point no. 2 shows a similar character of temperature distribution as a function of speed and manifold air pressure as at point no. 1. The increase in speed and pressure leads to the increase in temperature. Compare the systems without a turbocharger (Fig. 13) and with a turbocharger (Fig. 14). The lowest temperatures recorded for the lowest speed and the lowest manifold air pressure are $413.2^{\circ} \mathrm{C}$ for the base engine and $459.7{ }^{\circ} \mathrm{C}$ for the turbocharged one. The maximum values recorded at the highest pressure and speed are $674.6{ }^{\circ} \mathrm{C}$ for the Rotax engine without a turbocharger and $729.5^{\circ} \mathrm{C}$ for its modified version. These values and their distribution are similar to those obtained for point no. 1. There was no significant cooling of exhaust gases for such a small distance.

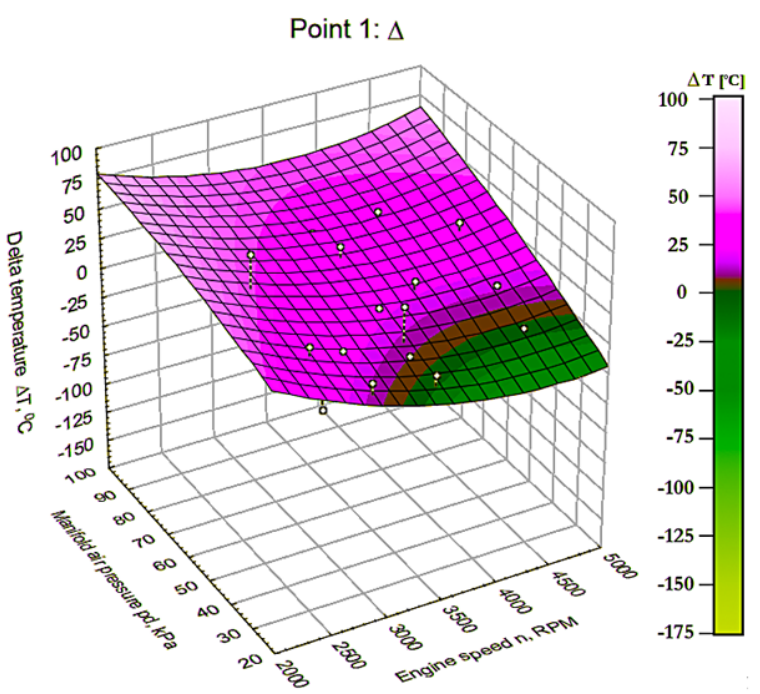

Fig. 12. Difference in the exhaust gas temperatures in the engine with and without turbocharging at point 1 as a function of engine speed and manifold air pressure 


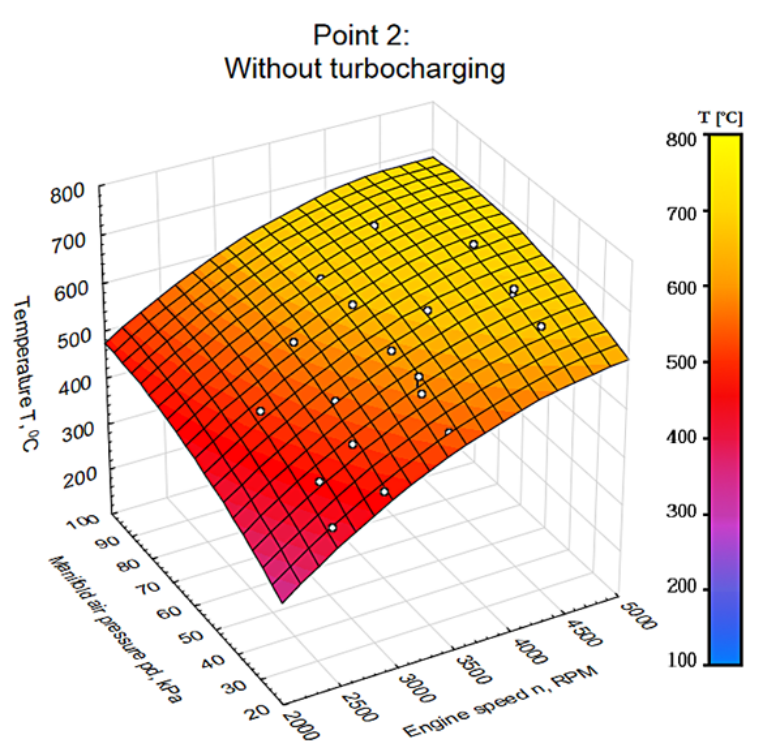

Fig. 13. Exhaust gas temperature at point 2 as a function of rotational speed and manifold air pressure in the engine without turbocharging

Point 2:

With turbocharging

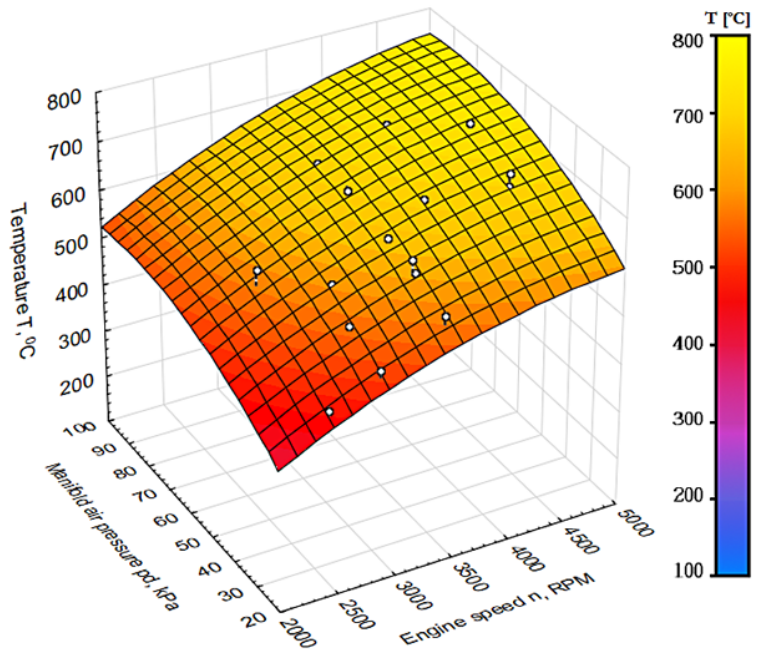

Fig. 14. Exhaust gas temperature at point 2 as a function of rotational speed and manifold air pressure in the engine with turbocharging

Figure 15 shows the characteristics of differences in the exhaust gas temperatures as a function of speed and manifold air pressure in the engines with and without a turbocharger. For the overall range of the measuring points, the temperature value for the turbocharged engine is higher than for the uncharged one. The highest increase of $92.8^{\circ} \mathrm{C}$ in the temperature of the exhaust gas in the turbocharger manifold is recorded for a speed of 2980 RPM and a manifold air pressure of $55 \mathrm{kPa}$. For $4530 \mathrm{RPM}$ and $29 \mathrm{kPa}$ of manifold

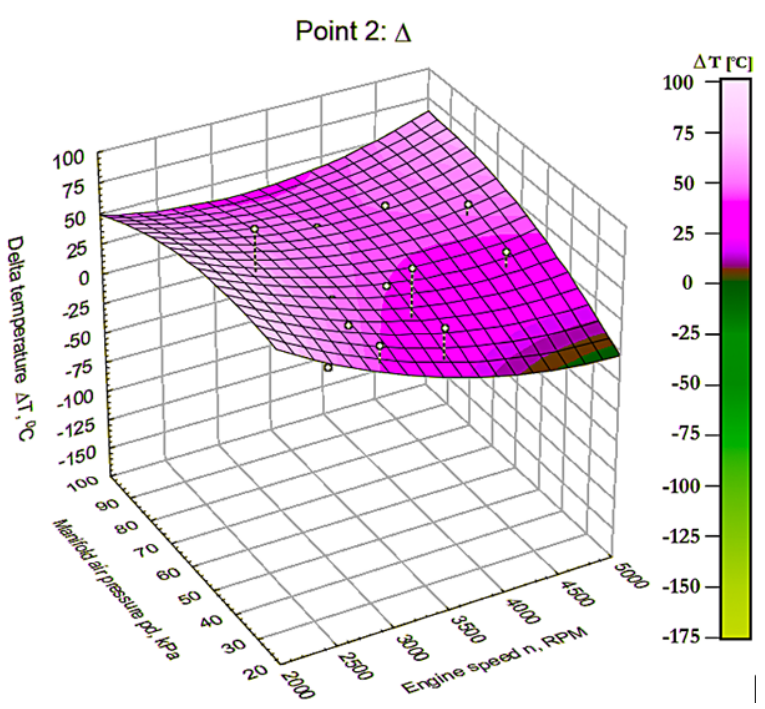

Fig. 15. Difference in the exhaust gas temperatures in the manifold with and without turbocharging at point 2 as a function of engine speed and manifold air pressure

air pressure, the temperature difference is lowest and oscillates around $3{ }^{\circ} \mathrm{C}$. The average exhaust gas temperature for the turbocharged engine is $617.3^{\circ} \mathrm{C}$, which is 41.9 degrees higher than for the engine without a turbocharger. At a distance of $180 \mathrm{~mm}$ from the cylinder - just before the turbine (downwards the intake manifold) the temperature increase is greater and amounts to about $6 \div 12 \%$ and as in the previous case mainly depends on the engine load. This means that the turbine constitutes a flow resistance, damming up the outflow of exhaust gases, which leads to an increase in temperature at this point. The greater the quantity of exhaust gas, the greater the accumulation, but even for small quantities there is an increase (about $5 \%$ ).

The temperature characteristics at measurement point no. 3 is shown in Figure 16. The exhaust gas temperatures at the silencer outlet show a directly proportional distribution as a function of manifold air pressure. The lowest temperature of $288.5^{\circ} \mathrm{C}$ occurs at the lowest pressure of $28 \mathrm{kPa}$ and speed 2360 RPM, whereas the highest temperature reaches $613.5^{\circ} \mathrm{C}$ at the highest manifold air pressure of $81 \mathrm{kPa}$.

The results show that the exhaust gases passing through the turbocharger cool down. The temperature distribution characteristics is shown in Figure 17. The highest recorded temperature is $474.2{ }^{\circ} \mathrm{C}$ and occurs at the highest pressure of $81 \mathrm{kPa}$ and speed of $3950 \mathrm{RPM}$. The lowest temperature, in turn, is only $169.6^{\circ} \mathrm{C}$ and occurs at 
Point 3:

Without turbocharging

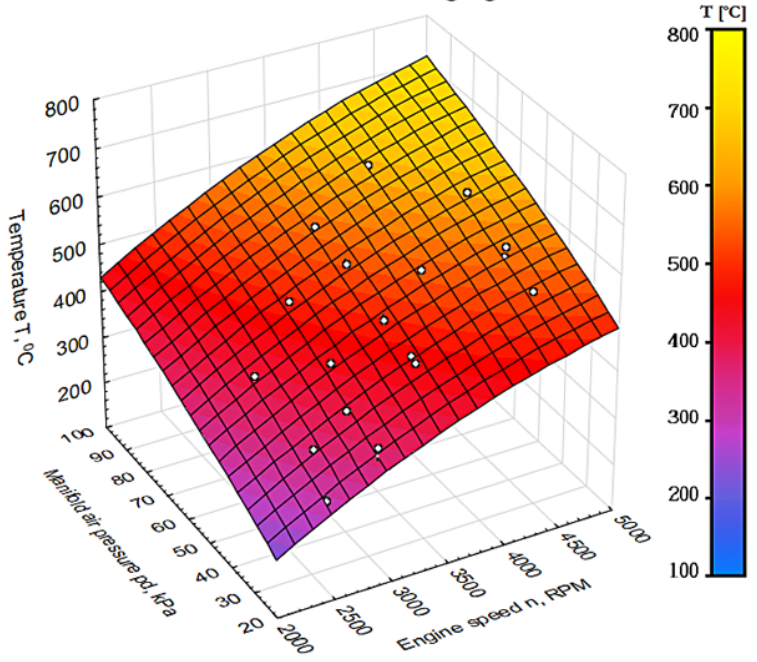

Fig. 16. Exhaust gas temperature at point 3 as a function of rotational speed and manifold air pressure in the engine without turbocharging

Point 3:

With turbocharging
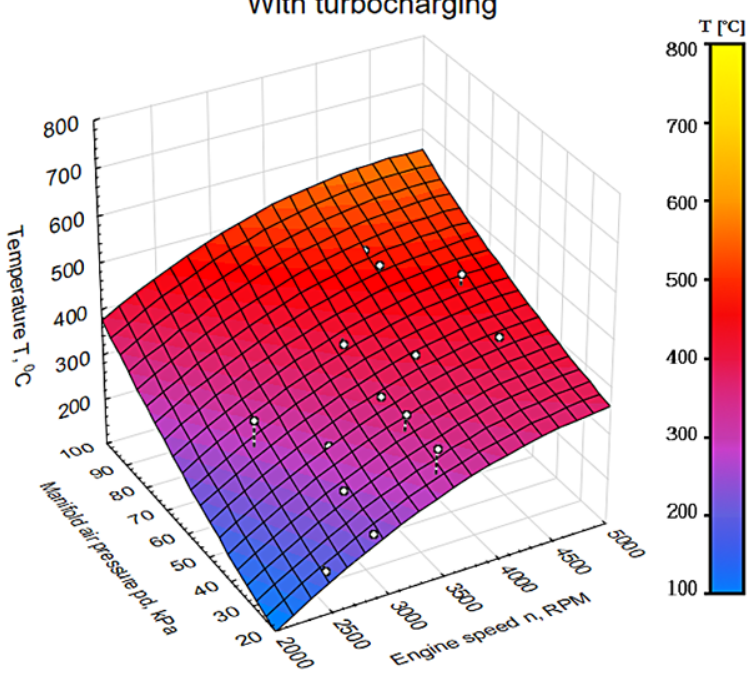

Fig. 17. Exhaust gas temperature at point 3 as a function of rotational speed and manifold air pressure in the engine with turbocharging

2360 RPM at the lowest manifold air pressure of $28 \mathrm{kPa}$. These values are significantly lower than for the undercharged engine.

The difference in the temperature distributions for the engine with and without the turbocharger is shown in Figure 18. Two characteristic phenomena can be observed here: a gradual increase of the temperature delta in the pressure ranging from 25 to $50 \mathrm{kPa}$ and its decrease with increasing speed. The characteristics of temperatures in the second part after exceeding 50 $\mathrm{kPa}$ will erase the reverse feature. An increase in

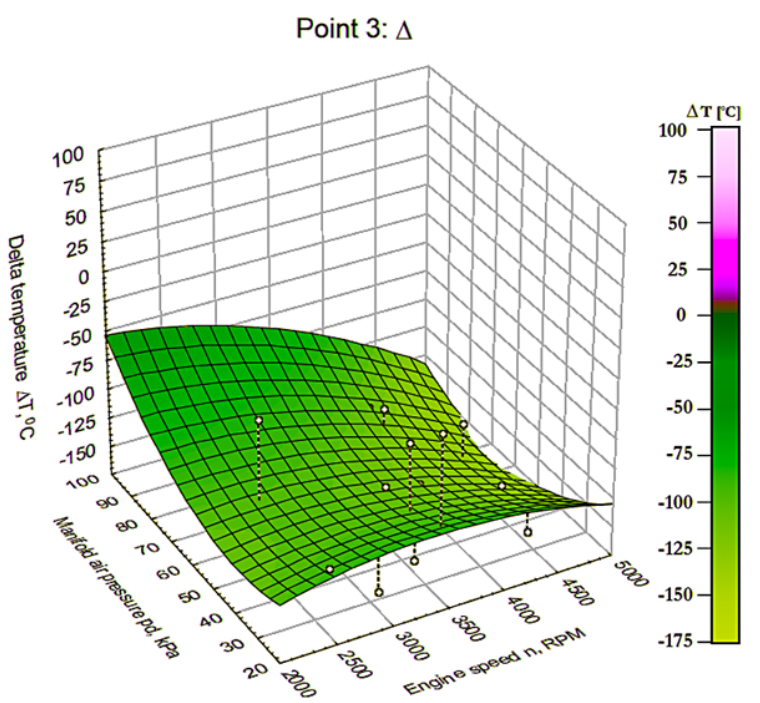

Fig. 18. Difference in the exhaust gas temperatures in the manifold with and without turbocharging at point 3 as a function of engine speed and manifold air pressure

the temperature difference as a function of speed increase reduces the temperature as the pressure in the manifold increases. The results obtained are inversely proportional to the values recorded before the turbocharger (Fig. 15). The average exhaust gas temperature for the engine without turbocharging is $473.9{ }^{\circ} \mathrm{C}$ and the average exhaust gas temperature for the turbocharged engine is $340.8^{\circ} \mathrm{C}$. At a distance of $1000 \mathrm{~mm}$ from the cylinder behind the turbine, the temperature drops by $20 \div 30 \%$. The greater the amount of exhaust gases and the higher the rotational speed, the greater this drop. This is due to the operation of the turbocharger unit. With a small amount of exhaust gases the turbine does not fulfill its task of expanding the exhaust gases and effectively removing energy from them. As a result, the expansion is lower and the temperature drop is smaller. An increase in the volume of exhaust gases (approaching the nominal operating point of the turbocharger) increases the efficiency of the turbocharger and increases energy extraction, leading to a greater drop in temperature.

\section{CONCLUSIONS}

The following conclusions can be drawn from the temperature distribution in the exhaust manifold of the Rotax 912 aircraft engine for the turbocharged and non-turbocharged exhaust system configurations: 
- The exhaust temperature in the exhaust manifold decreases with the distance from the cylinder head. This relationship occurs in both exhaust system configurations. The lowest temperature drop of $70.3{ }^{\circ} \mathrm{C}$ occurred only in the engine without turbocharging for $3950 \mathrm{RPM}$ and $81 \mathrm{kPa}$ of manifold air pressure. The highest gradient of the gas temperature from $589.9^{\circ} \mathrm{C}$ to $192.3^{\circ} \mathrm{C}$ occurred in the manifold with the turbocharger for $2603 \mathrm{RPM}$ and $31 \mathrm{kPa}$ of manifold air pressure.

- The maximum temperatures of exhaust gases were recorded at measurement point 1 and there was $713.3{ }^{\circ} \mathrm{C}$ for the engine without the turbocharger and $736.8{ }^{\circ} \mathrm{C}$ for the engine with the turbocharger.

- The introduction of turbocharging results in a small increase in temperature immediately after the cylinder (about $3 \div 6 \%$ ) and a much larger increase in temperature before the turbine (about $6 \div 12 \%$ ). This increase was more significant for the higher volume of exhaust gases - higher engine speed and manifold air pressure.

- The introduction of turbocharging results in a significant decrease in temperature behind the turbine $(20 \div 30 \%)$ which is the result of the energy taken from the exhaust gases by the turbocharger system.

To sum up, the introduction of turbocharging to a piston engine, apart from the obvious increase in power, also causes a change in heat load acting on the exhaust system. The part of the exhaust system before the turbine is more thermally stressed than in the non-charged system, but the increase is not very high (on average by $4 \%$ near the head and about $10 \%$ before the turbine). By using appropriate heat shields or properly directing air flowing around the engine, this additional heat can be easily dissipated without endangering the composite engine compartment covers. Behind the turbine, on the other hand, there is a significant decrease in the amount of heat (temperature) in the exhaust gases - on average by $25 \%$. This part of the exhaust system is therefore cooler and there are no problems in cooling it. Lowering this temperature is considerably easier if additional heat recovery elements like thermogenerator systems based on thermoelectric generator modules are applied.

\section{REFERENCES}

1. Lineberger R.S., Hussain A. 2018. Global aerospace and defense industry financial performance study Commercial aerospace sector performance decelerates, while defense sector continues to expand. (Relatório Técnico) - Deloitte [Internet], 1-64. Available from https://www2.deloitte.com/content/dam/ Deloitte/global/Images/infographics/gx-eri-globala-d-industry-financial-performance-study-2018.pdf

2. Pearce B. 2015. Economic Performance of the Airline Industry Outlook for 2016, 1-6.

3. Sádaba S., Martínez-Hergueta F., Lopes C.S., Gonzalez C., LLorca J. 2015. Virtual testing of impact in fiber reinforced laminates. Struct Integr Durab Adv Compos Innov Model Methods Intell Des, 247-70.

4. Zhang X., Chen Y., Hu J. 2018. Recent advances in the development of aerospace materials. Prog Aerosp Sci [Internet]. Elsevier Ltd, 97, 22-34. Available from: https://doi.org/10.1016/j.paerosci.2018.01.001

5. Collings N., Glover K., Campbell B., Fisher S. 2017. Internal combustion engine exhaust gas analysis. Int J Engine Res, 18, 308-32.

6. GAMA. 2019 Databook. 2020; Available from: https://gama.aero/wp-content/uploads/ GAMA_2019Databook_Final-2020-03-20.pdf

7. Czyż Z., Łusiak T., Czyz D., Kasperek D. 2016. Analysis of the Pre-Rotation Engine Loads in the Autogyro. Adv Sci Technol Res J, 10,169-76.

8. Xiang S., Liu Y Qiang, Tong G, Zhao W Ping, Tong S Xi, Li Y Dong. 2018. An improved propeller design method for the electric aircraft. Aerosp Sci Technol [Internet]. Elsevier Masson SAS, 78, 488-93. Available from: https://doi.org/10.1016/j. ast.2018.05.008

9. Ma S., Wang S., Zhang C., Zhang S. 2017. A method to improve the efficiency of an electric aircraft propulsion system. Energy [Internet]. Elsevier Ltd, 140, 436-43. Available from: https://doi. org/10.1016/j.energy.2017.08.095

10. Korczewski Z. 2016. Exhaust gas temperature measurements in diagnostics of turbocharged marine internal combustion engines Part II dynamic measurements. Polish Marit Res, 23, 68-76.

11. Dong Z., Liang L., Zhang W., Jiao L., Peng D., Liu Y. 2020. Simultaneous pressure and deformation field measurement on helicopter rotor blades using a grid-pattern pressure-sensitive paint system. Meas J Int Meas Confed [Internet]. Elsevier Ltd, 152:107359, Available from: https://doi. org/10.1016/j.measurement.2019.107359

12. Baines N., Wygant K. D., Dris A. 2010. The analysis of heat transfer in automotive turbochargers. J Eng Gas Turbines Power, 132:1-8. 
13. Birkigt A., Michels K., Theobald J., Seeger T., Gao Y., Weikl M.C., et al. 2011. Investigation of compression temperature in highly charged sparkignition engines. Int J Engine Res, 12, 282-92.

14. Arnau F.J., Martín J., Pla B., Auñón Á. 2021. Diesel. Engine optimization and exhaust thermal management by means of variable valve train strategies. Int J Engine Res, 22, 1196-213.

15. Jiang W., Shen T. 2021. Nonlinear observer-based exhaust manifold pressure estimation and fault detection for gasoline engines with exhaust gas recirculation. Int J Engine Res. 22, 1377-92.

16. Agency AS, European. Data Sheet Data Sheet [Internet]. EASA TCDS E.140 WSK PZL-Kalisz S.A. issue 0520150511 1.0. 2015. Available from: http://www.papersearch.net/view/detail. asp?detail_key=10000715

17. Rehan S. 2017. Dedicated Exhaust Gas Recirculation in Spark Ignition Engines. Adv Sci Technol Res J, 11, 44-50.

18. Park C., Ebisu M., Bae C. 2021. Effects of turbocharger rotational inertia on engine and turbine performance in a turbocharged gasoline direct injection engine under transient and steady conditions. Int J Engine Res [Internet]. SAGE Publications, 1468087420984600, Available from: https://doi. org/10.1177/1468087420984600

19. Lotko W, Lechowski M. 2020. Selected Issues on the Operation of the Internal Combustion Engine Turbocharger. Adv Sci Technol Res J, 14, 223-32.

20. Czarnigowski J.A., Jaklinski P., Ścisłowski K., Rękas D., Skiba K. 2020. The Use of a Low Frequency Vibration Signal in Detecting the Misfire of a Cylinder of an Aircraft Piston Engine. SAE Tech Pap. SAE International.

21. Guan W., Zhao H., Ban Z., Lin T. 2019. Exploring alternative combustion control strategies for low-load exhaust gas temperature management of a heavyduty diesel engine. Int J Engine Res, 20, 381-92.

22. Kumar M., Moeeni S., Kuboyama T., Moriyoshi Y. 2020. Performance improvement of turbocharged SI engine by post-oxidation enhancement in exhaust gas in-homogeneity. Int J Engine Res.

23. Rakopoulos C.D., Giakoumis E.G., Rakopoulos D.C. 2008. Study of the short-term cylinder wall temperature oscillations during transient operation of a turbocharged diesel engine with various insulation schemes. Int J Engine Res, 9, 177-93.

24. Czarnigowski J., Skiba K., Dubieński K. 2019. Investigations of the temperature distribution in the exhaust system of an aircraft piston engine. Combust Engines, 177,12-8.

25. Alger T., Gingrich J., Robers B. 2011. Cooled exhaust-gas recirculation for fuel economy and emissions improvement in gasoline engines. Int $\mathrm{J}$ Engine Res, 12, 252-64.
26. Lee S., Bae C. 2008. Design of a heat exchanger to reduce the exhaust temperature in a spark-ignition engine. Int J Therm Sci, 47, 468-78.

27. Qiu S., Yuan Z Cheng, Fan R Xun, Liu J. 2019. Effects of exhaust manifold with different structures on sound order distribution in exhaust system of four-cylinder engine. Appl Acoust [Internet]. Elsevier Ltd, 145, 176-83. Available from: https://doi. org/10.1016/j.apacoust.2018.06.021

28. Frosina E., Caputo C., Marinaro G., Senatore A., Pascarella C., Di Lorenzo G. 2017. Modelling of a Hybrid-Electric Light Aircraft. Energy Procedia [Internet]. Elsevier B.V. 126, 1155-62. Available from: https://doi.org/10.1016/j.egypro.2017.08.315

29. Royale A., Simic M., Lappas P. 2020. Engine exhaust manifold with thermoelectric generator unit. Int J Engine Res.

30. Tang H., Copeland C., Akehurst S., Brace C., Davies P., Pohorelsky L., et al. 2017. A novel predictive semi-physical feed-forward turbocharging system transient control strategy based on mean-value turbocharger model. Int J Engine Res, 18, 765-75.

31. Karamanis N., Martinez-Botas R.F. 2002. Mixed-flow turbines for automotive turbochargers: Steady and unsteady performance. Int J Engine Res, 3,127-38.

32. Grabowski Ł., Karpiński P., Magryta P. 2020. Simulation Research of the Influence of Compression Ratio on the Performance of an Aircraft Piston Diesel Engine. Adv Sci Technol Res J, 14, 175-81.

33. Kim S.K., Wakisaka T., Aoyagi Y. 2007. A numerical study of the effects of boost pressure and exhaust gas recirculation ratio on the combustion process and exhaust emissions in a diesel engine. Int J Engine Res., 8, 147-62.

34. Farzam R., Jafari B., Kalaki F. 2020. Turbocharged spark-ignition engine performance prediction in various inlet charged air temperatures fueled with gasoline-ethanol blends. Int J Engine Res.

35. Plotnikov L. V. 2021. Experimental research into the methods for controlling the thermal-mechanical characteristics of pulsating gas flows in the intake system of a turbocharged engine model. Int J Engine Res [Internet]. SAGE Publications, 1468087420987360, Available from: https://doi. org/10.1177/1468087420987360

36. Hu B., Akehurst S., Brace C. 2016. Novel approaches to improve the gas exchange process of downsized turbocharged spark-ignition engines: A review. Int J Engine Res, 17, 595-618.

37. Šeruga D., Hack M., Nagode M. 2016. Thermomechanical Fatigue Life Predictions of Exhaust System Components. MTZ Worldw, 77:44-9.

38. Keller M., Geiger S., Günther M., Pischinger S., Abel D., Albin T. 2020. Model predictive air path control for a two-stage turbocharged spark-ignition 
engine with low pressure exhaust gas recirculation. Int J Engine Res, 21, 1835-45.

39. Leahu C.I., Tarulescu S., Tarulescu R. 2018. The exhaust gas temperature control through an adequate thermal management of the engine. IOP Conf Ser Mater Sci Eng, 444.

40. Aghaali H, Ångström H.E., Serrano J.R. 2015. Evaluation of different heat transfer conditions on an automotive turbocharger. Int J Engine Res, 16, 137-51.

41. Alaviyoun S.S., Ziabasharhagh M. 2020. Experimental thermal survey of automotive turbocharger. Int J Engine Res., 766-80.

42. Ding C., Roberts L., Fain D.J., Ramesh A.K., Shaver G.M., McCarthy J, et al. 2016. Fuel efficient exhaust thermal management for compression ignition en- gines during idle via cylinder deactivation and flexible valve actuation. Int J Engine Res., 17, 619-30.

43. Bahri B., Aziz A.A., Shahbakhti M., Said M.F.M. 2013. Analysis and modeling of exhaust gas temperature in an ethanol fuelled HCCI engine. J Mech Sci Technol, 27, 3531-9.

44. Syta A., Czarnigowski J., Jakliński P. 2021. Detection of cylinder misfire in an aircraft engine using linear and non-linear signal analysis. Measurement, 174.

45. Guan W., Pedrozo V.B., Zhao H., Ban Z., Lin T. 2020. Miller cycle combined with exhaust gas recirculation and post-fuel injection for emissions and exhaust gas temperature control of a heavyduty diesel engine. Int J Engine Res, 21, 1381-97. 